\title{
FURTHER OBSERVATIONS ON "BLACKHEAD" IN TURKEYS
}

\author{
Ernest EDWARD TyZzer; MARShaL FAByAn, \\ AND \\ Nathan Chander Foot \\ From the Department of Comparatice Pathology, George Fabyan Foundation, Harvard \\ Medical School, Boston
}

The investigation of blackhead, continued during the summer of 1920, has yielded additional data which, although contributing to the general knowledge of the disease, leave certain practical questions still unanswered. Blackhead was transmitted by subcutaneous and intramuscular inoculation throughout the season, thus confirming previous results. ${ }^{1}$ The resistance of the virus to variations of temperature, and the question of its discharge from the mucous membranes were studied. Attempts to produce the disease other than by the previously employed method of inoculation of acute blackhead lesions have yielded some facts concerning the characteristics and distribution of Histomonas meleagridis, the parasite of blackhead. A study was also made of the relative frequency in normal and infected turkeys of the parasitic round-worm Heterakis papillosa.

On account of the varied character of the experiments, the data obtained will be summarized under separate headings.

\section{EFFECT OF TEMPERATURE ON VIRUS}

The resistance of the virus, as it occurs in the lesions of acute blackhead, was determined by inoculating turkeys with infectious material after its exposure to different temperatures. Livers showing lesions characteristic of acute blackhead were removed under aseptic precautions from freshly killed young turkeys and portions of the infected foci were distributed in sterile Petri dishes. Bits of these lesions after being subjected to freezing, refrigerator, or room temperature for definite periods of time, were then subcutaneously inoculated into turkeys from 3 to 6 weeks old. The results are given in table 1.

Received for pub.ication May 16, 1921.

1 Tyzzer, E. E., and Fabyan, M.: Jour. Infect. Dis., 1920, 27, p. 207. 
It is obvious from these results that the active virus is present in the lesions of a freshly killed turkey with acute blackhead, and that it probably deteriorates more rapidly at room temperature than at lower temperature. At refrigerator temperature -5 C.- it may remain alive

TABT.F 1

EFFect of TeMPERATURE ON VIRTS

\begin{tabular}{|c|c|c|c|c|c|c|}
\hline $\begin{array}{l}\text { Blackhead } \\
\text { Virus }\end{array}$ & Date & $\begin{array}{c}\text { Treatment of } \\
\text { Virus }\end{array}$ & $\begin{array}{l}\text { No. of } \\
\text { Turkey } \\
\text { Inoc1]- } \\
\text { lated }\end{array}$ & $\begin{array}{c}\text { Age } \\
\text { in } \\
\text { Days }\end{array}$ & $\begin{array}{l}\text { Weight } \\
\text { in } \\
\text { Grams }\end{array}$ & Result \\
\hline $\begin{array}{l}\text { Turkey } 20.86 . . \ldots \ldots \ldots \\
\text { (Spontaneous) } \\
\text { Liver lesions } \\
\text { Ibid. } \ldots \ldots \ldots \ldots \ldots \\
\\
\text { Ibid. } \ldots \ldots \ldots \ldots \ldots \\
\text { Ibid. } \ldots \ldots \ldots \ldots \ldots \\
\text { Ibid. } \ldots \ldots \ldots \ldots \ldots\end{array}$ & $\begin{array}{l}\text { June } 28 \\
\ldots \ldots \ldots \\
\ldots \ldots \ldots \\
\ldots \ldots \ldots\end{array}$ & $\begin{array}{l}\text { None. Used at } \\
\text { once } \\
48 \text { hours at } 5 \mathrm{C} \text {. } \\
48 \text { hours at } 22 \mathrm{C} \text {. } \\
7 \text { days at } 5 \mathrm{C} \text {. } \\
7 \text { days at } 22 \mathrm{C} \text {. }\end{array}$ & $\begin{array}{l}5 \\
6^{*} \\
7^{*} \\
8^{*}\end{array}$ & $\begin{array}{l}21 \\
23 \\
23 \\
28 \\
28\end{array}$ & $\begin{array}{l}260 \\
280 \\
290 \\
280 \\
300\end{array}$ & $\begin{array}{l}\text { Died of inoculated } \\
\text { blackhead on lith } \\
\text { day } \\
\text { Died of inoculated } \\
\text { blackhead on 13th } \\
\text { day } \\
\text { No infection } \\
\text { No infection } \\
\text { No infection }\end{array}$ \\
\hline $\begin{array}{l}\text { Turkey } 4 \ldots \ldots \ldots \ldots \ldots \\
\text { (Inoculated) } \\
\text { Liver lesions } \\
\text { Ibid. . . . . . . . }\end{array}$ & $\ldots \ldots$ & $\begin{array}{l}\text { Sone. Used at } \\
\text { once } \\
4 \text { days at } 5 \mathrm{C} \text {. }\end{array}$ & 10 & 24 & 310 & $\begin{array}{l}\text { Died of inoculated } \\
\text { blacklead on 11th } \\
\text { day } \\
\text { Died of inoculated } \\
\text { blackhead on 14th } \\
\text { day }\end{array}$ \\
\hline $\begin{array}{l}\text { Turkey } 12 \ldots . . . . . . . . . \\
\text { (Inoculated) } \\
\text { Subcutaneous and } \\
\text { liver lesions }\end{array}$ & July 28 & 5 days at $5 \mathrm{C}$. & $13^{*}$ & $4 i$ & $5 \pm 0$ & No infection \\
\hline $\begin{array}{l}\text { Purkey } 10 \ldots \ldots \ldots \ldots \\
\text { (Inoculated) } \\
\text { Liver lesions } \\
\text { Ibid. } \ldots \ldots \ldots \ldots \ldots\end{array}$ & $\begin{array}{l}\text { July } 20 \\
\ldots \ldots \ldots\end{array}$ & $\begin{array}{l}\text { None. Csed at } \\
\text { once } \\
\text { Frozen for } 5 \text { min- } \\
\text { utes after } 1 ? \\
\text { bours at } 1 \mathrm{C} \text {. }\end{array}$ & 2 & 4 & 500 & $\begin{array}{l}\text { Died of inoculated } \\
\text { blackhead on } 10 \text { th } \\
\text { day } \\
\text { No infection }\end{array}$ \\
\hline $\begin{array}{l}\text { Turkey 20.101........ } \\
\text { (Spontaneous) } \\
\text { Liver lesions }\end{array}$ & July 26 & $\bar{j}$ days at $\overline{\mathrm{C}}$. & $8^{*}$ & 54 & 730 & $\begin{array}{l}\text { No infection (The } \\
\text { fresh virus was } \\
\text { proved virulent by } \\
\text { cont rol inoeula } \\
\text { tion) }\end{array}$ \\
\hline $\begin{array}{l}\text { Turkey } 2 \ldots . . . . . . . . . \\
\text { (Inoculated) } \\
\text { Subcutaneous and } \\
\text { liver lesions }\end{array}$ & July 31 & 48 hours at $5 \mathrm{C}$. & $6^{*}$ & 56 & 730 & No infection \\
\hline $\begin{array}{l}\text { Turkey 19-12......... } \\
\text { (Inoeulated) } \\
\text { Subcutaneous } \\
\text { lesion }\end{array}$ & Det. 9 & $\begin{array}{l}\text { Frozen for } 5 \\
\text { minutes }\end{array}$ & $19-13$ & 104 & 2,050 & $\begin{array}{l}\text { No infection (The } \\
\text { control inocula- } \\
\text { tion of the oppo- } \\
\text { sitebreast with un- } \\
\text { treated virus pro- } \\
\text { duced infection) }\end{array}$ \\
\hline
\end{tabular}

* Died of spontaneous blackhead later on, showing turkey to be susceptible to the disease.

for at least 4 days, but it is quickly killed by actual freezing. Whether more resistant forms are present, which are not infective when injected into the tissues of the turkey, or whether such forms are produced elsewhere than in the blackhead lesions, are questions on which these data have no bearing. 


\section{INTRAVENOUS INOCULATION}

Turkeys were inoculated intravenously to determine whether certain organs or tissues were more favorable for the development of Histomonas than others. Certain of these turkeys also received injections of Niagara blue and India ink, but these dyes did not appreciably affect the results of the inoculation.

There were three objects in injecting these pigments: to stain the lesions vitally; to stain the parasites vitally, and to determine whether these dyes would have any deterrant effect on the growth of the parasite. The lesions were always vitally stained, but in such an irregular manner that no definite conclusions could be drawn as to the origin of the cellular reaction to the virus; the ink distribution was particularly irregular. Niagara blue was present in most of the phagocytic cells in the lesions, and it was possible to demonstrate granules of the dye occupying the same vacuole with one or more Histomonas. These granules were often grouped in two masses at the poles of a parasite, but always outside its body. The parasites were never vitally stained, and the presence of the dye in the lesions had no apparent effect on their growth.

Portions of liver or subcutaneous lesions from a freshly killed case of acute blackhead, were ground in a mortar with a small amount of normal salt solution. The resulting suspensions (in doses of 0.5 to $2 \mathrm{cc}$ ) were injected into a wing vein, usually the large superficial one extending across the elbow-joint at its inner surface. No immediate effect was noted, except in one instance (No. 30) in which a suspension of lung lesions was employed. This injection produced immediate death, attended by rapid clotting of the blood in the vessels. This phenomenon has already been noted by others' in work on poultry. ${ }^{2}$ The experiments are briefly tabulated in table 2 .

It is apparent from these results that the injection of blackhead virus directly into the blood stream produces disease in only a relatively small proportion of cases, in striking contrast to subcutaneous inoculation, which practically always causes infection. In those cases in which infection follows intravenous inoculation (see table 2, nos. 26, 28 and 29 ) one or two large initial lesions usually develop in the lungs and smaller secondary lesions distributed in various organs, in order of frequency as follows: lung, liver, kidney, proventriculus, pancreas, small intestine, spleen, cecum and ovary. Occasionally, however, as wide a dissemination of lesions may be associated with either subcutaneous blackhead or the natural disease. The process may extend from the initial lesion of the lung through the thoracic wall, destroy-

2 Bang, Oluf: Centralbl. f. Bakteriol., I, O., 1908, 46, p. 468. 
TABLE 2

IXTRAVENOLS INOCLLATION

\begin{tabular}{|c|c|c|}
\hline Turkey & Intravenous Injection * & Findings \\
\hline 7 & $\begin{array}{l}\text { Aug. } 21.2 .5 \text { c c } \\
\text { Suspension of liver lesions } \\
\text { Aug. } 23.2 \text { c e } \\
\text { Suspension of liver lesions } \\
\text { (48 hours in refrigerator) }\end{array}$ & $\begin{array}{l}\text { Spontaneous blackhead } \\
\text { Aug. } 21 \text {. Symptoms noted before jnjected } \\
\text { Aug. } 26 \text {. Died (5th day) } \\
\text { no lesions except in caeca and liver } \\
\text { (Injections caused no appreciable change } \\
\text { in course of disease) }\end{array}$ \\
\hline $14 t$ & $\begin{array}{l}\text { Aug. } 6 . \quad 1 \text { e } \\
\text { Suspension of liver lesions } \\
\text { (Some of suspension escaped into } \\
\text { surrounding tissues) }\end{array}$ & $\begin{array}{l}\text { Sibcutaneous bluckhead } \\
\text { Aug. } 19 \text {. Killed ( } 13 \text { th day) } \\
\text { Local lesion on wing and secondaty } \\
\text { lesions in lunge and liver } \\
\text { Spontaneous blackhead (early) } \\
\text { Both cacea show early lesions }\end{array}$ \\
\hline $15 \dagger$ & $\begin{array}{l}\text { Aug. } 6 . \quad 1 \text { e } \\
\text { Suspension of liver lesions } \\
\text { (Most of suspension escaped into } \\
\text { surrounding tissues) }\end{array}$ & $\begin{array}{l}\text { Subcutaneous blackhead } \\
\text { Aug. 17. Iilled (11th day) } \\
\text { Loeal lesions on wing, numerous small } \\
\text { secondary lesions in lungs }\end{array}$ \\
\hline $16+$ & $\begin{array}{l}\text { Aug. } 6 . \quad 0.5 \text { e e } \\
\text { Suspension of liver lesions }\end{array}$ & $\begin{array}{l}\text { Failed to infect } \\
\text { Aug. } 20 \text {. Killed; normal }\end{array}$ \\
\hline 17 & $\begin{array}{l}\text { Aug. } 6 . \quad 1 \mathrm{c} c \\
\text { Suspension of liver lesions } \\
\text { Aug. 21. } 1.5 \mathrm{c} c \\
\text { Thick suspension of liver lesions }\end{array}$ & $\begin{array}{l}\text { Both intravenous injections failed to } \\
\text { infect } \\
\text { Aug. } 28 \text {. Breast inoeulated with virus } \\
\text { Sept. 7. Killed (10th day) } \\
\text { Subcutancous blackhead } \\
\text { Local lesion on breast, secondary lesions } \\
\text { in lungs and liver } \\
\text { (Susceptibility demonstrated) }\end{array}$ \\
\hline 26 & $\begin{array}{l}\text { Sept. } 9.2 \text { ce } \\
\text { Suspension of liver lesions }\end{array}$ & $\begin{array}{l}\text { Visceral blackhead } \\
\text { Sept. } 24 \text {. Died (13th day) } \\
\text { No lesion on wing } \\
\text { Extension of process from primary } \\
\text { focus in lung through wall of thorax } \\
\text { Smaller lesions in lungs, liver, kidney, } \\
\text { ovary, panereas, proventrieulus, small } \\
\text { intestine and one cecum }\end{array}$ \\
\hline 28 & $\begin{array}{l}\text { Aug. } 26 . \quad 1.5 \mathrm{ce} \\
\text { Suspension of liver lesions }\end{array}$ & $\begin{array}{l}\text { Visceral blackhead } \\
\text { Sept. } 9 \text {. Moribund and kilked (14th day) } \\
\text { No lesion on wing } \\
\text { Primary lesion replacing much of right } \\
\text { lung } \\
\text { Secondary lesions in liver and kidneys }\end{array}$ \\
\hline 29 & $\begin{array}{l}\text { Aug. } 26.2 \mathrm{ec} \\
\text { Suspension of liver lesions } \\
\text { Sept. } 9.2 \mathrm{c} \mathrm{c} \\
\text { Suspension of liver lesions } \\
\text { Sept. } 24.2 \mathrm{c} \text {. } \\
\text { Suspension of subcutaneous lesion } \\
\text { Oet. } 8 \text {. } 2 \mathrm{c} \\
\text { Rich suspension of subcutaneous } \\
\text { lesion }\end{array}$ & $\begin{array}{l}\text { Visceral blackheud } \\
\text { Oet. 25. Died (17th duy after Iast in- } \\
\text { jection) } \\
\text { No lesion on wing } \\
\text { Primary lesion in lung, extending } \\
\text { through thoracie wall with destruction } \\
\text { of intervertebral ligament and in- } \\
\text { volvement of periosteum } \\
\text { Secondary lesions in liver, spleun, kir- } \\
\text { neys, proventriculus and duodenum }\end{array}$ \\
\hline 30 & $\begin{array}{l}\text { Aug. } 28 ., 2 \mathrm{c} c \\
\text { Suspension of liver lesions } \\
\text { Sept. } 9.2 \mathrm{e} \mathrm{c} \\
\text { Suspension of liver lesions } \\
\text { Sept. } 13.1 \mathrm{c} \mathrm{c} \\
\text { Suspension of lung lesion }\end{array}$ & $\begin{array}{l}\text { No infection from first or second injec- } \\
\text { tion injuction caused subden death } \\
\text { Third injo tung tissue } \\
\text { owing to use of lun }\end{array}$ \\
\hline 31 & $\begin{array}{l}\text { Sept. } 9.2 \mathrm{ce} \\
\text { Suspension of liver lesions } \\
\text { Sept. } 24.2 \mathrm{c} \text {. } \\
\text { Suspension of subcutantous lesion } \\
\text { Oet. } 8.1 .7 \mathrm{c} \text {. } \\
\text { Thick suspension of subeutaneous } \\
\text { lesion }\end{array}$ & $\begin{array}{l}\text { Visceral blackhead } \\
\text { Oct. } 19 \text {. Breast inoculation with virus } \\
\text { Oct. } 30 \text {. Killed (zod day after last in- } \\
\text { jection } \\
\text { Suboutancous blackbead } \\
\text { Toeal lesion on breast } \\
\text { Lesions of lungs. Dancreas, and cecum } \\
\text { of similar size }\end{array}$ \\
\hline
\end{tabular}

* The material used in each intratenous injection, with the exception of thosp injected on Oet. 8 was proved virulent by control subcataneons inoeulation of other tirkeys.

t Injected with Niagara blue and India ink at intervals. 
ing muscles, ligaments and other tissues. Although the skeletal muscles are readily invaded, no metastatic lesions have thus far been found in them.

IM MUNITY

The frequent failure of intravenous inoculation to produce any evidence of infection led us to consider the possibility of obtaining an artificial immunity by this procedure. It was found, however, that if the intravenous injections were repeated a sufficient number of times, the disease was eventually produced (table 2 , no. 29). Furthermore, a negative intravenous inoculation failed to protect the turkey against later subcutaneous inoculation, and the disease resulting from the latter ran its usual fatal course. Intravenous inoculation of a turkey ill with spontaneous blackhead did not appreciably alter the course of this disease or produce additional lesions.

There is little doubt that recovery sometimes occurs in natural blackhead, notwithstanding its usual fatal course. Turkeys showing all the characteristic signs of blackhead and derived from flocks in which blackhead was present have been known to recover. One turkey (no. 25) which showed weakness, loss of weight and sulphur droppings late in November, at the age of $51 / 2$ months, improved later on and when killed on Dec. 22, had healing lesions in one cecum and scattered depressions with some scar tissue in the liver.

The immunity in such a recovered case of spontaneous blackhead has not been tested as yet by subsequent subcutaneous inoculations. That immunity follows recovery from blackhead is indicated, however, by the failure of a subcutaneous inoculation of active virus to infect a turkey (43) which had recovered (whether or not because of special treatment) from inoculated blackhead.

The occurrence of a small localized cecal lesion and a few liver lesions in a turkey killed late in Dec., which had not shown any symptoms of blackhead, suggests the possibility that slight attacks may pass unrecognized. The disease, however, may prove fatal even in mature birds. We have recently received a report of the disease occurring in several adult hen turkeys, two of which died. The liver of one of these submitted for examination showed characteristic lesions of blackhead. A year old male said to have lost weight and shown sulphur droppings at about the same time, now appears normal. It is thus quite apparent that those turkeys which fail to become infected in early life may, contrary to popular belief, later on develop blackhead. It is probably true, however, that resistance increases with age so that the outlook is better both in respect to the frequency of blackhead and the prognosis of the cases that occur. 
EMETIN TREATMENT

The efficiency of emetin in the treatment of entamebiasis of man suggested its use in this disease. Of three turkeys 72 days old, inoculated on Sept. 24 with bits of an active subcutaneous lesion, 2 received subcutaneous injection of emetin hydrochloride at intervals, while the third served as a control. Emetin treatment was commenced in one turkey (43) on the day following inoculation and was repeated at intervals of 24 or 48 hours, the dose being sufficient to cause loss of appetite and weakness. A total of $9 \mathrm{mg}$. of the drug was given in 10 injections during a period of 11 days. This treatment did not prevent the development of the disease, the local lesion developing to considerable size- $2.5 \times 1.5 \times 1.0 \mathrm{~cm}$.--but later regressed, and the turkey was shown by subsequent subcutaneous inoculation to be immune to blackhead. A similar course of treatment was commenced in the other turkey (42) 3 days after inoculation. The disease was not appreciably affected in this case, death occurring 14 days after inoculation. The control or untreated turkey (41) on account of weakness, was killed on the 11th day, and showed typical inoculated blackhead. It is evident that early sublethal doses of emetin hydrochloride fail to prevent the development of subcutaneously inoculated blackhead. While the recovery of one of the treated turkeys may have been due to the treatment, this isolated instance would not warrant such a conclusion at present, for one of the turkeys inoculated earlier in the season showed a spontaneous regression of the disease when killed.

\section{SUBCONJUNCTIVAL INOCULATION}

To ascertain whether flagellated forms of Histomonas escape from lesions in a readily accessible mucous membrane, a turkey (21) was inoculated beneath the conjunctiva near the anterior angle of the eye. Eight days after the inoculation there was a local swelling composed of opaque, whitish tissue beneath the conjunctiva, accompanied by a watery discharge from the eye. The swelling of the subconjunctival tissues increased and the eyeball was gradually covered by the edematous nictitating membrane. There was no ulceration up to the 12 th day, when a slight abrasion appeared, possibly due to rubbing the affected side of the head against the feathers. Careful microscopic examination of the discharge showed an occasional rounded organism, but none that assumed the appearance of an active flagellate. Scrapings of the lesion after killing the turkey showed large numbers of Histomonas present. 
ATTEMPTS TO PRODUCE BLACKHEAD BY INTESTINAL ROUTE

With the view of determining the source and distribution of the blackhead parasite, apart from the lesions of the disease, various: materials were fed and injected.

Ingestion of Virus.-Since the alimentary tract is always primarily affected in the naturally acquired disease, it might be expected that feeding of the lesions would result in infections. Three turkeys 2 weeks old were fed repeatedly with fresh subcutaneous, liver and lung lesions, but none developed blackhead as the result of this procedure. One of these on two occasions was placed in a cold room and was thoroughly chilled by partial immersion in ice-water on the first day for four minutes and on the following day for 8 minutes. This turkey apparently throve on the treatment and grew faster than any of the others hatched from the same setting.

Injection of Virus into Cecum.-That the virus, under normal physiologic conditions, might be destroyed in passing through the alimentary tract before reaching the ceca, was considered as a possible basis for the failure to infect by feeding fresh lesions. Accordingly, laparotomy was performed on 3 turkeys and a suspension of ground subcutaneous and lung lesions was injected directly through the wall of the cecum into the lumen. Precautions were taken to avoid undue trauma of the cecal wall, and the introduction of the virus into the tissue. In no instance did the injection of such virus alone result in infection.

That some form of Histomonas, not found in acute lesions, might be necessary for the penetration of the cecal mucosa before the natural infection could be initiated, was considered a possibility. It might be expected that such forms would occur in the cecal "core," which is of the nature of a cast of the cavity of the cecum, being composed chiefly of exudate deposited in successive layers. Accordingly, a suspension of ground-up cecal "core" taken directly from a freshly killed case of blackhead, was injected into the ceca of two turkeys, but in neither did blackhead develop.

Partial or temporary obstruction of the cecum, as suggested by the large cores frequently found in spontaneous blackhead, was simulated by injections of melted paraffin (melting-point 42 C.) into the lumen. One turkey received an intracecal injection of paraffin and after a brief illness discharged this material in the form of a cast of the cecum. Two turkeys were given an intracecal injection of paraffin followed by an injection of virus. The larger of these ( 83 days old) showed 
no evidence of infection as the result of the procedure. The smaller turkey, 30 days old (weighing 280 gms.), developed blackhead. However, as the initial lesion in the cecum appeared at the point of puncture, it seems probable that infection resulted from the introduction of virus into the tissue where the cecal wall was punctured. It would not be safe to conclude that obstruction was the determining factor in this single positive case for the delicacy of the ceca in so small a turkey makes it almost impossible to inject into the lumen without some leakage.

Ingestion of Heterakis Ova.-In preparation for this experiment, turkeys hatched in an incubator were transferred to a freshly whitewashed brooder. Attached to the brooder was a cage, which, except for the first two or three days, was covered with mosquito netting to keep out flies and other insects. Owing to cold weather and the failure of the brooder lamp, many of these specially hatched turkeys succumbed before they could be utilized. We were obliged therefore, to employ smaller groups than was originally intended, and to include for one group, older turkeys that had been fed blackhead lesions previously. On Sept. 22nd the turkeys were separated into 3 groups, each group being placed in a screened coop on clean grass:

Group A: Two turkeys (48 and 49, hatched Aug. 20) were fed large amounts of fresh blackhead lesions on three different occasions (Sept. 22, 24 and Oct. 5). These turkeys, although exposed to cold, dampness and accunulating filth, remained normal up to Nov. 11, and were then used for other experiments, and subsequently proved to be susceptible to inoculated blackhead. At necropsy they showed no evidence of cecal disease.

Group B: Three turkeys (50, hatched Aug. 20, and 51 and 52, hatched Aug. 31) were fed ripe ova of Heterakis papillosa on Sept. 22 and 24. One died of blackhead in 18 and 2 in 19 days after the first feeding of Heterakis ova, and each showed typical lesions of spontaneous blackhead.

Group C: This group consisted of 3 older turkeys, hatched Aug. 3, that had been fed blackhead lesions without apparent result. One of these (47, that had failed to show the normal weekly increase in weight) was killed on Sept. 24 and showed no lesions of blackhead and no Heterakis present. The other two (45 and 46) were fed ripe Heterakis ova and blackhead lesions on Sept. 24 and Oct. 5 . One died of blackhead in 22 days and the other in 23 days after the first feeding of Heterakis ova. 
The results of this experiment confirm those of Graybill and Smith," and indicate clearly that a disease in every respect identical with spontaneous blackhead may be experimentally produced by feeding the ripened ova of Heterakis papillosa. Apparently it is not necessary, under ordinary conditions, to furnish blackhead virus in addition to the worm ova, for brooder turkeys (Group B) placed on clean ground, without access to insects, contracted the disease when fed the worm eggs alone. It must be noted, however, that the precautions for the comparative isolation of these young turkeys from the time of hatching, did not prevent the appearance of protozoa in their cecal discharges. Although the brooder had been thoroughly whitewashed, the young turkeys which succumbed to cold and exposure showed myriads of intestinal flagellates, chiefly Tetratrichomonas gallinarum ${ }^{4}$ with fewer Eutrichomastix gallinarum. ${ }^{4}$ Several also showed numerous oöcysts of Eimeria avium. ${ }^{6}$

Whether or not the material containing Heterakis ova represents a source of the blackhead virus under the given circumstances may possibly be answered by more carefully conducted experiments. On account of the lateness of the season few newly hatched (and hence presumably clean) turkeys were available for subsequent experimentation.

Two of these were fed ripe Heterakis ova on Oct. 11, the day after they were hatched. They were then transferred to a clean chamber which served as a brooder, and were provided with sterilized food, grit and water. One of these, a weakling, died 10 days after the ingestion of Heterakis ova. Necropsy showed no evidence of blackhead and strange to say, no worms. Both ceca showed rather soft, friable cores which were found on microscopic examination to be composed of fibrin, cellular exudate and bacteria. A careful examination failed to reveal any protozoa.

The other turkey remaining apparently normal, was again fed Heterakis ova on Oct. 22 and 23. On account of increase in size it became necessary to remove him from the above chamber and on Nov. 1 (19 days old), he was placed with other slightly younger turkeys in a brooder outdoors. This turkey now failed to gain in weight and was killed on Nov. 8. There was a core in one cecum, the walls of both ceca were somewhat thickened, and numerous ill-defined,

3 Jour. Exper. Med., 1920, 31, p. 647.

4 Martin, C. H, and Robertson, M.: Quart. Jour. Micr. Sc., 1911, Part 1, 57, p. 53 and p. 58.

5 Kofoid, C. A., and Swezy, O.: Proc. Am. Acad. Arts and Sciences, 1915, 51, p. 289.

B Silvestrini and Rivolta: Giorn. Anat. Fisiol., 1873. 
small, grayish lesions were present in the liver, which proved to be blackhead on histologic examination. Only 2 immature worms were found on careful search of the cecal contents.

A control turkey, hatched Oct. 12, and kept in the outdoor brooder, received a single dose of the same Heterakis material on Oct. 22. This bird died on Nov. 5, of blackhead at a much more advanced stage than was found in the previous turkey, which received its last dose of Heterakis ova on Oct. 23, and was killed Nov. 8. Forty-two worms were counted, without a very complete search, from one cecum of the control turkey.

While the result is not wholly conclusive, the early stage of the disease seen in the "clean chamber" turkey strongly suggests that blackhead was contracted after the bird had been transferred to the outdoor brooder. It is a peculiar fact that only two worms developed in the "clean chamber" turkey, which received 3 doses of Heterakis ova, whereas the control turkey showed 42 worms in one cecum alone as the result of a single feeding of the same Heterakis material.

The subsequent feeding of Heterakis ova to several other turkeys resulted in the production of blackhead. The data of all the Heterakisfed turkeys are collected in the accompanying table.

The attempt to eliminate all sources of blackhead infection other than the Heterakis material has not yielded definite results, so that it will be necessary to repeat this experiment.

\section{INOCULATION TEST FOR PRESENCE OF HISTOMONAS}

In order to test the possible infectiousness of various materials, including certain intestinal protozoa and Heterakis material, a series of turkeys was inoculated subcutaneously or intramuscularly.

Intestinal Protozoa.-Cecal contents of turkeys containing various species of protozoa were diluted with salt solution and inoculated into the breast. There were usually two or more species of protozoa in each cecal discharge used, but as a number of samples were employed, all the known cecal parasites of the turkey, with the exception of Trichomonas eberthi ${ }^{4}$ were available. The turkeys inoculated with cecal material invariably showed toxic symptoms during the first 24 hours after inoculation. There was local swelling at the site of inoculation, but this subsided in all instances without ulceration, and in no case did blackhead develop. The following protozoa were present in great numbers in the various samples injected: Tetrachilomastix 
TABLE 3

Feeding of Heterakis Ova

\begin{tabular}{|c|c|c|c|c|}
\hline Experiment & Turkey & Hatched & Treatment & Result \\
\hline \multirow{2}{*}{$\begin{array}{c}\text { Group } \mathcal{A} \\
\text { Fed blackhead }\end{array}$} & 48 & Aug. 20 & \multirow{2}{*}{$\begin{array}{l}\text { Sept. } 22 \text {. Fed subcutaneous } \\
\text { and lung lesions } \\
\text { Sept. 24. Fed lung lesions } \\
\text { Oct. 5. Fed subeutaneous } \\
\text { and lung lesions }\end{array}$} & $\begin{array}{l}\text { Remained normal } \\
\text { Nov. } 26 \text {. Died } \\
\text { (Inoculated blackhead } \\
\text { of Nov. 11) }\end{array}$ \\
\hline & 49 & Aug. 20 & & $\begin{array}{l}\text { Remained normal } \\
\text { Dec. } 20 . \text { Killed } \\
\text { (Inoculated blackhead } \\
\text { of Dee. 11) }\end{array}$ \\
\hline \multirow{3}{*}{$\begin{array}{l}\text { Group B } \\
\text { Fed ripe } \\
\text { Heterakis } \\
\quad \text { ova }\end{array}$} & 50 & Aug. 20 & \multirow{3}{*}{$\begin{array}{l}\text { Sept. 22. Fed Heterakis ova } \\
\text { collected Sept. } 7 \text { from } \\
\text { chickens } \\
\text { sept. 24. Fed Heterakis ova } \\
\text { collected Sept. 10 from } \\
\text { chickens }\end{array}$} & $\begin{array}{l}\text { Cecal infection } \\
\text { Oet. 5. Sulphur drop- } \\
\text { pings } \\
\text { Oct. 11. Died } \\
\text { Blackhead lesions left } \\
\text { ceeum and liver } \\
\text { 125 immature Heterakis }\end{array}$ \\
\hline & 51 & Aug. 31 & & $\begin{array}{l}\text { Cecal infection } \\
\text { Oct. } 10 . \text { Died } \\
\text { Blackhead lesions left } \\
\text { cecum and liver } \\
42 \text { immature Heterakis }\end{array}$ \\
\hline & 52 & Aug. 31 & & $\begin{array}{l}\text { Cecal infection } \\
\text { Oct. 11. Died } \\
\text { Blackhead lesions left } \\
\text { cecum and liver } \\
\text { 128 immature Heterakis }\end{array}$ \\
\hline \multirow{2}{*}{$\begin{array}{l}\text { Group O } \\
\text { Fed blackhead } \\
\text { and ripe Het- } \\
\text { erakis ova } \\
\text { (Group O had } \\
\text { previously been } \\
\text { fed blackhead } \\
\text { lesions on Aug. } \\
17,18 \text { and 19) }\end{array}$} & 45 & Ang. 3 & \multirow{2}{*}{$\begin{array}{l}\text { Sept. 24. Fed fresh black- } \\
\text { head lesions (subcutane- } \\
\text { ous and Heterakis ova } \\
\text { collected Sept. 10 from } \\
\text { chiekens } \\
\text { Oet. 5. Fed fresh black- } \\
\text { head lesions (lung and } \\
\text { subcutaneous and Het- } \\
\text { erakis ora collected Sept. } \\
10 \text { from chickens }\end{array}$} & $\begin{array}{l}\text { Cecal infection } \\
\text { Oct. 8. Sulphur drop- } \\
\text { pings } \\
\text { Oct. 17. Died } \\
\text { Blackhead lesion right } \\
\text { cectum and liver } \\
\text { (Secondary inycosis) } \\
73 \text { immature Heterakis }\end{array}$ \\
\hline & 46 & Aug. 3 & & $\begin{array}{l}\text { Oecal infection } \\
\text { Oct. 8. Stulphur drop- } \\
\text { pings } \\
\text { Oct. } 16 . \text { Died } \\
\text { Blackhead lesions left } \\
\text { cecum, liver and kid- } \\
\text { ney } \\
18 \text { immature Heterakis }\end{array}$ \\
\hline $\begin{array}{l}\text { Oontrol for } \\
\text { Group C }\end{array}$ & 47 & Aug. 3 & None & $\begin{array}{l}\text { Control } \\
\text { Sept. 24. Killed } \\
\text { No lesions } \\
\text { No Heterakis found }\end{array}$ \\
\hline \multirow[t]{2}{*}{$\begin{array}{l}\text { "Clean } \\
\text { chamber" }\end{array}$} & $\overline{58}$ & Oet. 10 & $\begin{array}{l}\text { Oct. 11. Fed Heterakis ova } \\
\text { collected Sept. } \tau \text { from } \\
\text { chickens }\end{array}$ & $\begin{array}{l}\text { No infection } \\
\text { Oct. } 21 \text {. Died } \\
\text { Both ceca contained } \\
\text { delicate cores. Mi- } \\
\text { croscopically no evi- } \\
\text { dence of blackhead } \\
\text { No Heterakis found }\end{array}$ \\
\hline & 59 & Oct. 10 & $\begin{array}{l}\text { Oct. 11. Fed Heterakis ova } \\
\text { collected Sept. } 7 \text { from } \\
\text { chickens } \\
\text { Oct. } 22 . \text { Fed same material } \\
\text { Oct. } 23 . \text { Fed same material } \\
\text { Nov. 1. Moved to outdoor } \\
\text { brooder }\end{array}$ & $\begin{array}{l}\text { Cecal infection (early) } \\
\text { Nov. } 8 \text {. No gain in } \\
\text { weight. Killed } \\
\text { Blackhend lesions both } \\
\text { ceca and liver } \\
2 \text { immature Heterakis }\end{array}$ \\
\hline \multirow[t]{2}{*}{$\begin{array}{c}\text { Control for } \\
\text { No. } 59\end{array}$} & 60 & Oet. 12 & $\begin{array}{l}\text { Oct. 22. Fed Heterakis ova } \\
\text { collected } \\
\text { chickens }\end{array}$ & $\begin{array}{l}\text { Cecal infection } \\
\text { Nov, } 5 \text {. Died } \\
\text { Blackhead lesions both } \\
\text { coca and liver } \\
42 \text { immature Heterakis } \\
\text { (one cecum) }\end{array}$ \\
\hline & 68 & Oet. 12 & $\begin{array}{l}\text { Nov, 18. Fed Heterakis ova } \\
\text { collected Sept. } 10 \text { from } \\
\text { chickens }\end{array}$ & $\begin{array}{l}\text { Cecal infection } \\
\text { Dec. } 1 . \quad \text { Sulphur drop- } \\
\text { pings } \\
\text { Dec. } 4 . \quad \text { Killed } \\
\text { Blackhead lesions both } \\
\text { ceca and liver } \\
\text { 87 immature Heterakis }\end{array}$ \\
\hline
\end{tabular}


gallinarum,, ${ }^{4,7}$ Eutrichomastix gallinarum, ${ }^{4,5}$ Tetratrichomonas gallinarum, ${ }^{4}$ Entamoeba gallinarum, ${ }^{8}$ Pygolimax gregariniformis, ${ }^{8}$ and Eimeria avium. ${ }^{6}$

Contents of Diseased Ceca.-This material was collected from a case of blackhead by searing through the wall of the diseased cecum in order to avoid contamination with Histomonas from the infected tissue. The injection on two separate occasions of such material into the breast of a normal turkey failed to produce blackhead.

Cecal Mucosa.-The subcutaneous injection of scrapings of the cecal mucosa of several old turkeys also resulted negatively.

Heterakis.-Heterakis freshly obtained from cases of blackhead were washed several times in salt solution and injected subcutaneously into a turkey with negative result.

Heterakis Ova.-Material containing ripe Heterakis ova, which when fed to turkeys produced blackhead, was injected into the breast of a normal turkey with negative result.

Cultures of Ameba and Flagellates.-Cultures obtained from the Heterakis material containing a species of ameba and a flagellate not yet classified, but belonging to the Bodonidae, were also injected into turkeys with negative result.

Tracheal Washings.-The washings from the trachea in a case of inoculated blackhead with extensive lung involvement, were inoculated subcutaneously without effect.

Sequestrum.-In order to determine to what extent Histomonas survives in the necrotic material in a subcutaneous lesion a turkey was inoculated with a bit of the necrotic portion. No infection resulted. Later the sequestrum and surrounding tissue from a healing subcutaneous lesion was implanted in the breast of a normal turkey with negative result.

Table 4 gives the data of these various experiments.

It is possible that blackhead virus, even if present, might have been incapable of developing in the presence of the acute inflammatory reaction resulting from the injection of the associated material. Unfortunately the control, that is, the inoculation of a mixture of blackhead virus and cecal contents, was omitted, but will be carried out in future work.

- La Fonseca: Brazil Medico, 1915, 29, p. 281.

s Tyzzer, E. E.: Jour. Med. Res., 1920, 41, p. 199. 
TABLE 4

INOCULATION EXPERIMENTS

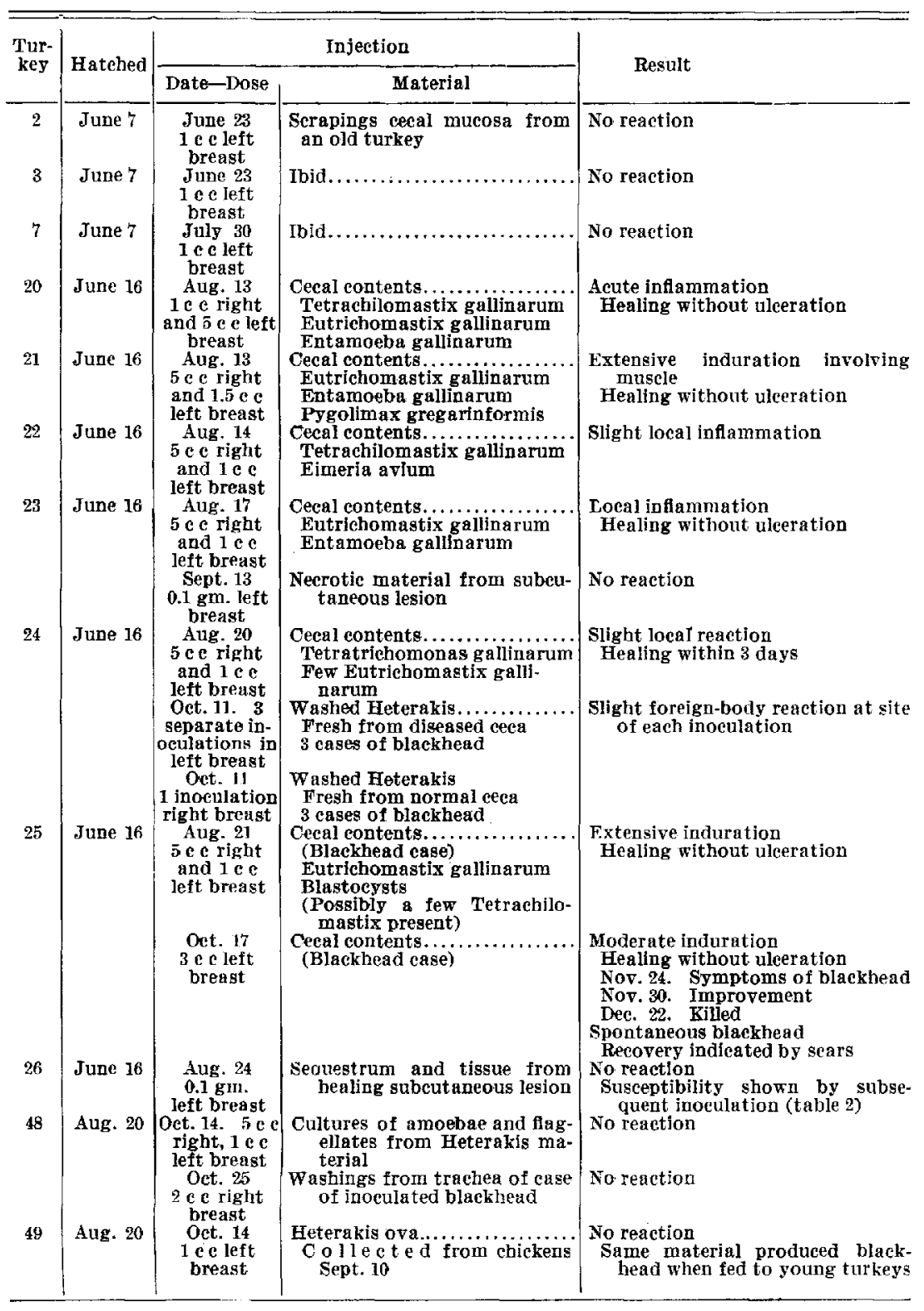




\section{ASSOCIATION OF HETERAKIS PAPILLOSA WITH SPONTANEOUS}

TLACKHEAD

This worm appears to be very generally distributed in common fowls and turkeys. Absent in newly-hatched stock, the prevalence of these parasitic worms depends on the environment in which the birds are reared. Turkeys have been kept entirely free from worms for several months after hatching, by isolation on clean grassed-over areas. When reared on ground previously occupied by turkeys, or when allowed access to hen-coops, young turkeys soon acquire considerable numbers of these worms. It is probable that the warmth of the summer months favors the development of the Heterakis ova so that greater infestation occurs as the season progresses. During the past summer a record was kcpt of the number of Heterakis found in practically all turkeys necropsied.

Blackhead cases appeared spontaneously among the turkeys kept in the "old yard," that is, the enclosure which had been used for the two previous summers for experimental work on blackhead. The majority of the cases (8) occurred in July and August, but there were also 2 cases in December. None of these cases showed over 23 worms, and in 2 of the earlier cases none could be found on careful search of the entire cecal contents.

A comparison of the number of worms found in our 8 cases of spontaneous blackhead, and 38 turkeys without cecal infection, shows no predominance in the former series. The examination of 14 cases of blackhead from outside sources also showed some in which no worms could be found, others with few, and yet others in which worms were numerous. It is evident that there is no close relationship between the incidence of blackhead and the number of worms present in our series of turkeys.

It appears probable that a pathologic condition is necessary for the production of blackhead, a condition which may result not only from overwhelming invasion by Heterakis, but also from other, at present, unknown causes. We have noted rudimentary casts or cores in the ceca of young turkeys in which there was microscopically no evidence of blackhead, but it is possible that such conditions, with Histomonas present in the cecum, may lead to the invasion of the tissues by this organism. The histologic study of such cores, developing in the absence of blackhead, demonstrates their pathologic character-since they consist chiefly of a fibrinous and cellular exudate intermingled with bacteria, but occasionally may also show red blood corpuscles. On 
cross-section their laminated structure indicates that they are formed by successive deposits of exudate. The mucous membrane may show no more than slight infiltration and degeneration of the surface epithelium in such instances.

\section{EXPOSURE TO COMMON FOWLS}

One turkey was kept in the care of a common hen from the time of hatching on September 22. When 18 days old it was placed in a hen-yard for a short time each morning, and when 54 days old it was kept constantly with a small flock of hens. Symptoms of blackhead appeared 13 days later at the age of 67 days. Considerable resistance was shown by this turkey, as it lived 14 days after showing symptoms. Dying at the age of 83 days, chronic blackhead lesions were found at necropsy. Heterakis was present in greater numbers (279) in this bird than in any of the turkeys to which the parasite had been fed experimentally. A large proportion of the worms were fully matured. This indicates that young turkeys may gradually acquire many times the number of Heterakis than would certainly suffice to produce blackhead when fed experimentally on a single occasion. The result of this experiment also confirms our previous findings as to the danger of exposing young turkeys to the haunts of common fowls. Isolation thus appears to furnish the only practical means at present available of limiting blackhead. ${ }^{9}$

EXPOSURE TO TURKEY DROPPINGS OF PREVIOUS SEASON

Three turkeys 9 days old were confined in a cage for 47 days on the accumulated droppings and soil of the night-quarters of the previous season's flock. The attempt was made to exclude flies and insects from this cage by screening but, on the contrary, the cage proved itself a very effective fly-trap on warm days, catching swarms of blue-bottle flies on which the young turkeys gorged themselves. Although this cage became exceedingly filthy, so that the turkeys were at all times dirty and bedraggled in appearance, a much more rapid gain in weight was made than in a control turkey which was hatched on the same date and had the range of a large yard of clean grass. The phenomenal growth of these turkeys closely confined in filthy quarters is somewhat surprising, but may be accounted for by the abundance of insect food available.

2 Tyzzer, E. E., and Fabyan, M.: Commonwealth of Mass., Dept. of Agri., Dept. Bull. No. 15, March, 1921. 
INOCULATION OF THE TURKEY EMBRYO WITH BLACKHEAD VIRUS

Four turkey eggs which had been incubated for 12 days were inoculated with active blackhead virus, 2 through the upper and 2 through the lower surface, with the intention of inoculating the amniotic and yolk sacs. The examination of 3 of these, 6 days after inoculation showed one to be sterile, one with a dead embryo, and the third with a living, apparently normal embryo. The fourth egg, on further incubation, failed to hatch, but when opened showed a full-sized, normally developed, turkey chick. In none of these eggs was there any evidence of blackhead.

\section{SUSCEPTIBILITY OF OTHER SPECIES TO BLACKHEAD}

As stated in a previous paper, ${ }^{1}$ it was found possible to infect newly-hatched chickens by inoculation. The local lesions were selflimited, although in one instance there were secondary lesions in the lungs. It was also demonstrated that a certain proportion of pigeons $(30 \%)$ were susceptible to the subcutaneous inoculation of blackhead. The lesions regressed, however, after the ninth or tenth day.

An attempt has been made this season to infect other species by inoculation. Many European sparrows were inoculated, but without result. Two ducks (Indian runners) were inoculated without result.

Three guinea-chicks were inoculated; local lesions developed in each one, but regression followed after the 12th day. Microscopic examination of the lesions showed extensive cellular reaction, moderate numbers of parasites, but no necrosis.

One pheasant was inoculated when 39 days old. A small local lesion developed slowly and persisted until the bird was killed on Sept. 7, 17 days after inoculation. The local lesion measured $1.3 \times 0.5 \times 0.5 \mathrm{~cm}$. and showed microscopically a marked cellular reaction and numerous parasites, but no evidence of necrosis. No other lesions were noted.

SUM MARY

The virus of blackhead, as found in turkey liver lesions, survives for at least 4 days at $5 \mathrm{C}$., deteriorates more rapidly at $22 \mathrm{C}$. and is immediately destroyed by freezing.

As compared with subcutaneous inoculation, intravenous inoculation results much less frequently in infection. The failure of an intravenous inoculation to cause infection is not due to an insusceptibility of the turkey employed; for if this procedure is repeated a 
sufficient number of times, infection follows. Furthermore, turkeys that have been inoculated intravenously with negative result may now be successfully inoculated subcutaneously. That intravenous inoculation should so frequently fail to produce infection is the more remarkable since dissemination of the virus by the blood stream almost invariably occurs in infected turkeys.

These results clearly show that immunity is not produced by negative intravenous inoculation; it has been found impossible, however, to infect a turkey that has recovered from inoculated blackhead. Although not yet demonstrated, it may be expected that turkeys recovering from spontaneous blackhead will also prove immune. Resistance to blackhead seems to increase with age, so that fewer maturing birds show symptoms of infection and recovery is evidently more frequent. It is not improbable that mild attacks may pass unrecognized in large turkeys.

The treatment of the turkey by repeated subcutaneous injections of emetin hydrochloride in doses sufficiently large to produce toxic symptoms, fails to prevent the development of subcutaneous blackhead, even though commenced immediately after inoculation. Of two cases thus treated, one recovered; but spontaneous recovery from blackhead occasionally occurs.

Repeated injections of Niagara blue and India ink (whether before or after inoculation), do not apparently alter the course of the disease.

The study of the conjunctival discharge in subconjunctival blackhead furnishes no evidence that Histomonas escapes from a mucous surface in flagellated form. This is consistent with the findings in previous histologic studies of cecal lesions in which no intermediate stages were found between Histomonas and any of the flagellates in the cecal glands or contents.

Attempts to produce blackhead by the intestinal route show that the disease is not caused by the mere feeding of infected tissues. The injection into the lumen of the normal cecum of either virus from active lesions, or the substance of "cores" from ceca infected with blackhead, may not result in blackhead. Temporary obstruction has been experimentally produced by the injection of melted paraffin into the lumen of the cecum. This alone, or in conjunction with blackhead virus, fails to cause cecal infection.

The feeding of large numbers of ripe ova of Heterakis papillosa to isolated groups of turkeys has resulted in typical blackhead. It was noted, however, that turkeys raised in fairly strict isolation acquired 
great numbers of intestinal protozoa before leaving the brooder. Apparently ripe Heterakis ova may fail to develop when fed to young turkeys kept in a clean chamber and furnished with sterilized food and water, but they readily develop in those having access to the soil. The reason for this is not apparent.

The subcutaneous inoculation of various materials - cecal discharges containing various species of cecal flagellates and amebae; blastocytes, cultures of protozoa of cecal origin, exudate from a cecum showing blackhead lesions, ripe Heterakis ova and washed Heterakis from several cases of blackhead-have all failed to produce blackhead. It is possible that the acute inflammation resulting from the injection of cecal contents may interfere with the development of Histomonas, were the latter present in the material used. Although this organism is sometimes found in considerable numbers in the air-spaces, in stained sections of pulmonary lesions of inoculated turkeys, the injection of tracheal washings from a single case resulted negatively. The results of the inoculation of necrotic portions of subcutaneous lesions, or material from healing lesions indicate that Histomonas does not persist long in dead tissues.

While blackhead appears to develop quite constantly as the result of feeding ripe Heterakis ova, the study of a large number of turkeys indicates that the disease may occur when this worm is rare or entirely absent from the ceca. It is also apparent that young turkeys do not develop blackhead as readily from the slow acquisition of Heterakis ova, as they do from large overwhelming doses, such as those given experimentally. These findings suggest that the invasion of the tissue by Histomonas in spontaneous blackhead is not dependent solely on the presence of Heterakis but on pathologic conditions that may occur not only in association with this parasite worm but also quite independent of it.

Soil contaminated with the droppings of turkeys of the previous season may not of itself furnish the conditions which would cause young turkeys kept thereon to develop blackhead.

A self-limited infection, similar to that produced in young chickens and pigeons, follows the inoculation of blackhead into young pheasants and guinea-chicks. All of these species show a much more extensive tissue reaction to the virus than that which occurs in the more susceptible turkey. Both the European sparrow and Indian Runner duck appear to be nonsusceptible. 
The turkey embryo is apparently unsuitable as a medium for the development of Histomonas; for incubated turkey eggs were inoculated with blackhead virus without result.

Blackhead has followed the exposure of a young turkey to common fowls, confirming the experience of the previous years and emphasizing the importance of isolation in rearing turkeys. 